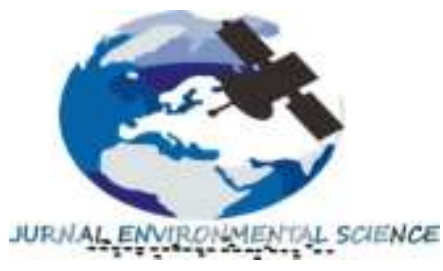

Jurnal Environmental Science

Volume 4 Nomor 1 Oktober 2021

p-ISSN : 2654-4490 dan e-ISSN : 2654-9085

Homepage at : ojs.unm.ac.id/JES

E-mail:jes@unm.ac.id

\title{
KEARIFAN LOKAL LILIFUK DI NUSA TENGGARA TIMUR DALAM PENGELOLAAN SUMBER DAYA LAUT BERKELANJUTAN
}

\author{
Hasriyanti $^{1}$, Alief Saputro ${ }^{2}$, Anugrah Isromi ${ }^{3}$ \\ ${ }^{123}$ Jurusan Geografi Fakultas Ilmu dan Pengetahuan Alam \\ Universitas Negeri Makassar \\ Email: yantisakijo@ymail.com ${ }^{1}$, aliefsaputro23@gmail.com ${ }^{2}$,anugrahisromi@gmail.com ${ }^{3}$
}

\begin{abstract}
Local wisdom is an important sector that continues to be preserved by the Indonesian people, one of which is the local wisdom of lilifuk in East Nusa Tenggara. Lilifuk is one of the local wisdoms in the East Nusa Tenggara Province of Indonesia which has become a community culture in terms of managing marine resources. This study aims to determine the sustainable management of marine resources that exist in the local wisdom of lilifuk in East Nusa Tenggara. The type of research used is qualitative through literature studies. The scope of this research area is in East Nusa Tenggara, precisely in Kuanheun Village, West Kupang District, West Kupang Regency. In this study, the data collection method used is documentation, which is tracking written sources containing various themes and topics discussed. The data have been collected and analyzed using descriptive methods that describe what is being investigated. The results of this study indicate that in the management of lilifuk, the people of East Nusa Tenggara mobilize all elements to maintain and preserve lilifuk local wisdom, this is evidenced by the existence of five elements of society that play an important role, namely religious leaders, traditional leaders, village government, communities, and people who come from. from outside the village each of these elements has a responsibility and function according to the given role.
\end{abstract}

Keywords: local wisdom; lilifuk; marine resources

\begin{abstract}
ABSTRAK
Kearifal lokal merupakan salah sektor penting yang terus di lestarikan oleh masyarakat Indonesia, salah satunya adalah kearifan lokal lilifuk yang ada di Nusa Tenggara Timur. Lilifuk merupakan salah satu kearifan lokal yang ada di Provinsi Nusa Tenggara Timur Indonesia yang sudah menjadi budaya masyarakat dalam hal mengelola sumber daya laut. Penelitian ini bertujuan untuk mengetahui pengelolaan sumberdaya laut berkelanjutan yang ada pada kearifan lokal lilifuk di Nusa Tenggara Timur. Jenis penelitian yang digunakan adalah kualitatif melalui studi literature Cakupan wilayah penelitian ini adalah di Nusa Tenggara Timur tepatnya di Desa Kuanheun Kecamatan Kupang Barat Kabupaten Kupang Barat. Pada penelitian ini metode pengumpulan data yang digunakan adalah dokumentasi, yaitu melacak sumber tertulis yang berisi berbagai tema dan topik yang dibahas. Data yang telah dikumpulkan dan dianalisis dengan metode deskriptif yang menggambarkan apa yang sedang diselidiki. Hasil penelitian ini menunjukkan bahwa dalam pengelolaan lilifuk masayarakat Nusa Tenggara Timur mengerahkan seluruh elemen untuk menjaga dan melestarikan kearifan lokal lilifuk, hal ini dibuktikan dengan adanya lima elemen masyarakat yang berperan penting yakni tokoh agama, tokoh adat, pemerintah desa, masyarakat, dan orang yang berasal dari luar desa yang masing-masing unsur tersebut memiliki tanggung jawab dan fungsinya sesuai peran yang diberikan.
\end{abstract}

Kata Kunci: kearifan lokal; lilifuk; sumber daya laut 


\section{PENDAHULUAN}

Keragaman budaya dan kearifan lokal merupakan ciri khas Indonesia sebagai negara yang kaya akan sumber daya. Secara lughowi, kearifan lokal juga dikonsepsikan sebagai kebijakan setempat "local wisdom" atau pengetahuan setempat "local knowledge" atau kecerdasan setempat "local genious". Keberagaman suku dan etnik memiliki sistem dan pendekatannya sendiri dalam memahami dan bersikap terhadap pengelolaan sumber daya alam (Awaliyah et al., 2020). Sehingga keragaman budaya yang tumbuh dan berkembang di setiap etnis harus diakui keberadaannya (Syarif et al., 2016).

Kearifan lokal (local wisdom) merupakan kecerdasan manusia yang dimiliki oleh kelompok etnis tertentu yang diperoleh melalui pengalaman masyarakat (Rahyono, 2009). Menurut (Fajarini, 2014) local wisdom juga diartikan sebagai pandangan hidup dan ilmu pengetahuan yang diimpelemtasikan di berbagai strategi kehidupan berupa aktivitas masyarakat lokal dalam menjawab berbagai masalah dalam pemenuhan kebutuhan mereka.

Masyarakat adat merupakan sekumpulan orang yang hidup bersama dalam satu wilayah yang memiliki hubungan keterikatan sebagai satu kerukunan (Surbakti \& Leonak, 2020). Kearifan lokal yang terdapat pada beberapa kelompok atau masyarakat adat di Indonesia banyak mengandung nilai luhur budaya bangsa yang masih kuat menjadi identitas karakter warga masyarakatnya (Priyatna, 2017). Pengamalan nilai-nilai kearifan lokal sampai hari ini masih terus dilaksanakan oleh segelintir masyarakat Indonesia di berbagai sektor, seperti perekonomian, pertanian, perkebunan, perikanan bahkan pelestarian hutan dan lingkungan. Menurut penelitian yang dijabarkan (Yulisti et al., 2014) menjelaskan bahwa keberadaan lilifuk merupakan suatu bentuk kearifan lokal pengelolaan sumber daya perikanan.

Local wisdom memiliki sifat berkesinambungan dengan kepercayaan yang turun temurun terkait antara hubungan masyarakat dengan lingkungan. Menurut beberapa ahli, kearifan lokal dibedakan dengan budaya dalam suatu masyarakat tertentu. Implementasi kearifan lokal yang ada pada kehidupan masyarakat adat merupakan segala bentuk pengetahuan, keyakinan, pemahaman maupun wawasan serta adat istiadat atau etika masyarakat yang menuntun perilaku kehidupan mereka di dalam komunitas ekologisnya (Keraf, 2010). Pengelolaan sumber daya laut yang selama ini dilakukan tidak lepas dari pengaruh kebudayaan masyarakat pesisir, hal ini sangat berpengaruh mengingat peran serta masyarakat dalam pengelolaan sumber daya perikanan dalam bentuk kearifan lokal merupakan wujud tanggung jawab mereka dalam melestarikan sumber daya sehingga dapat memberikan manfaat berkelanjutan (Yulisti et al., 2014). Bagi masyarakat adat, lingkungan tempat tinggal mereka merupakan simbol dari sebuah harga diri (Sulaiman, 2010).

Kearifan lokal Lilifuk adalah cara mengelola sumber daya laut yang dikenal di Nusa Tenggara Timur. Lilifuk merupakan suatu kawasan di perairan laut yang berbentuk kolam yang tergenang pada saat air laut surut. Menurut (Surbakti \& Leonak, 2020) lilifuk merupakan salah satu pengelolaan sumber daya perikanan Community Based Management (CBM) yang berupa pemberian wewenang, tanggung jawab dan kesempatan kepada masyarakat untuk mengelola sumber daya kelautan dan perikanan sendiri dengan memperhatikan kebutuhan, keinginan, tujuan dan aspirasinya.

Pengololaan wilayah pesisir memiliki satu atau lebih sistem lingkungan (ekosistem) dan sumber daya pesisir (Rinaldi et al., 2020). Hal tersebut dipengaruhi oleh indikator bahwa wilayah pesisir merupakan interface antara kawasan laut dan darat yang saling mempengaruhi dan dipengaruhi satu sama lainnya, baik secara biogeofisik maupun sosial ekonomi (Christiawan \& Budiarta, 2017). Sumber daya laut yang terbatas harus diolah sedemikian rupa sehingga ekosistem laut dapat secara berkala dimanfaatkan sehingga perlu adanya usaha pengelolaan sumberdaya laut yang berkelanjutan. Menurut (Suman \& Satria, 2013) pemanfaatan sumber daya secara berkelanjutan (sustainable mangement) dalam perikanan timbul karena adanya isu global tentang terbatasnya sumber daya perikanan, hal tersebut sejalan dengan kebutuhan akan sumber daya perikanan yang terus meningkat akibat meningkatnya jumlah populasi manusia di dunia.

Agar pemanfaatan sumber daya laut oleh masyarakat pesisir, perlu adanya program yang dilakukan secara berkelanjutan yang menjadi acuan dalam pengelolaan sumber daya yang mesti dikelola secara rasional. Sehingga pada penelitian ini, peneliti mencoba menggali lebih lanjut terkait pengelolaan sumberdaya laut berkelanjutan yang ada pada kearifan lokal lilifuk di Nusa Tenggara Timur. 


\section{METODE}

Penelitian ini merupakan jenis penelitian kualitatif melalui studi literatur. Metode studi literatur atau sering dikenal sebagai studi pustaka adalah data yang diperoleh, selanjutnya dikompulasi dan dianalisis hingga disimpulkan sehingga mendapatkan kesimpulan mengenai tujuan penelitian. Tahapan penelitian dilaksanakan dengan menghimpun sumber kepustakaan, baik primer maupun sekunder (Darmalaksana, 2020). Jenis data yang digunakan adalah data sekunder. Metode pengumpulan data adalah studi pustaka. Menurut (Sugiyono, 2019) studi pustaka merupakan penelitian dimana data tidak diperoleh dari lapangan tetapi dari perpustakaan atau tempat lain yang menyimpan refrensi, dokumen-dokumen yang berisi data yang telah teruji validitasnya. Metode yang akan digunakan untuk pengkajian ini studi literatur.

Cakupan wilayah penelitian ini adalah di Nusa Tenggara Timur tepatnya di Desa Kuanheun Kecamatan Kupang Barat Kabupaten Kupang Barat. Pada penelitian ini metode pengumpulan data yang digunakan adalah dokumentasi, yaitu melacak sumber tertulis yang berisi berbagai tema dan topik yang dibahas. Data yang telah dikumpulkan dan dianalisis dengan metode deskriptif yang menggambarkan apa yang sedang diselidiki.

Secara terstruktur pada penelitian ini, langkah awal yang dilakukan adalah mengumpulkan dan mempelajari data hasil penelitian yang sama oleh peneliti sebelumnya yang dilanjutkan dengan menambahkan data untuk mendukung penelitian ini melalui jurnal, buku, dan internet. Setelah data dikumpulkan dan dipelajari, dilanjutkan dengan pengolahan data dan analisis data dengan analisis deskriptif. Kontribusi ini diharapkan untuk mengetahui pengelolaan sumber daya berkelanjutan pada kearifan lokal lilifuk.

\section{HASIL DAN PEMBAHASAN}

\section{Hasil}

Desa Kuanheun merupakan salah satu desa yang ada di Kecamatan Kupang Barat, Kabupaten Kupang Barat, Nusa Tenggara Timur. Desa Kuanheun secara umum merupakan dataran rendah dengan tingkat kemiringan 0,10. Desa Kuanheun terletak di pesisir pantai yang memiliki iklim yang tidak jauh berbeda dengan daerah-daerah lainnya di Provinsi Nusa Tenggara Timur yaitu beriklim tropis, suhu rata-rata $31,5^{\circ} \mathrm{C}$ yang memiliki jumlah bulan hujan selama tiga bulan dengan curah hujan $1000 \mathrm{~mm}$. Secara tipologi wilayahnya terbentang dan memanjang dari selatan ke utara dengan luas wilayah $21,46 \mathrm{~km}^{2}$ dengan kategori Desa Swakarya (Kupang, 2018). Pemanfaatan dari luas wilayah tersebut antara lain untuk pemukiman seluas $658 \mathrm{Ha}$, persawahan $280 \mathrm{Ha}$, perkebunan (p)128 Ha, kuburan $40 \mathrm{Ha}$, pekarangan $740 \mathrm{Ha}$, taman $100 \mathrm{Ha}$, perkantoran $25 \mathrm{Ha}$, dan $175 \mathrm{Ha}$ untuk prasarana umum lainnya.

Secara administrasi, wilayah Desa Kuanheun sebelah utara berbatasan dengan Desa Bolok, sebelah selatan berdampingan dengan Desa Oematnunu, sebelah barat bersebalahan dengan laut, dan sebelah timur bertetangga dengan Kelurahan Batakte. Desa Kuanheun terbagi menjadi 5 Dusun, $6 \mathrm{RW}$ dan $12 \mathrm{RT}$, yang mana masing-masing wilayah dikepalai oleh pejabat dusun yang disebut dengan Kepala Dusun, Pejabat RW yang disebut dengan Ketua RW, Pejabat RT yang disebut dengan Ketua RT. Desa dengan jarak $7 \mathrm{~km}$ dari ibukota kecamatan dan $56 \mathrm{~km}$ dari ibukota kabupaten ini, pada tahun 2017 memiliki jumlah penduduk sebanyak 1.553 jiwa, terdiri dari 809 jiwa laki-laki dan 744 jiwa perempuan dengan tingkat kepadatan penduduk 72 jiwa per $\mathrm{km}^{2}$ (Kupang, 2018). Desa dengan fasilitas pendidikan berupa SD, SMP, SMA masing-masing satu buah dan belum memiliki TK ini sebagian besar masyarakatnya bermata pencaharian sebagai petani. Dalam sektor peternakan juga ada beberapa yang mengembangkan seperti peternakan sapi sebanyak 1.025 ekor, kambing 673 ekor, dan babi 634 ekor (Kupang, 2018). Sedangkan masyarakat yang berkerja sebagai nelayan tercatat sebanyak 4 orang sebagai nelayan penuh, 60 orang nelayan sambilan, dan 100 orang nelayan sambilan tambahan. Desa yang masih mempunyai hutan lindung 
seluas 214,60 ha dan hutan rakyat seluas 214,60 ha ini sebagian besar menganut agama Kristen Protestan yakni sebanyak 1.456 orang, sedangkan 24 orang beragama Kristen Katolik (Kupang, 2018).

Desa Kuanheun berbatasan dengan Laut Sawu yang memliki sumber daya perikanan dan laut yang cukup potensial antara lain seperti, berbagai jenis ikan laut, padang lamun, hutan mangrove, terumbu karang dan juga rumput laut. Sumber daya tersebut dimanfaatkan sebagai bahan makanan dan sisanya dijual untuk mendapatkan uang. Lokasi desa yang strategis ini membuat masyarakat melakukan budidaya rumput laut sekaligus menangkap ikan pelagis dan ikan karang. Melimpahnya ikan karang di sekitan Desa Kuenheun dikarenakan masih banyaknya terumbu karang di pesisir pantai desa. Jenis karang yang ada di pesisir desa terdiri atas karang lunak, karang bercabang, dan karang otak. Pada sektor perikanan dan kelautan, perairan laut desa Kuanheun memiliki pengelolaan secara tradisional melalui kearifan lokal lilifuk.

Dewasa ini peningkatan aktivitas pembangunan di wilayah pesisir semakin hari semakin nyata terjadi, tidak terkecuali wilayah pesisir yang berada di Teluk Kupang Desa Kuanheun Kecamatan Kupang Barat. Tanpa disadari proses pembangunan yang dilakukan oleh pihak swasta maupun masyarakat setempat telah memberi dampak yang kurang baik terhadap lingkungan pesisir. Apalagi skala prioritas dari kegiatan pembangunan tersebut hanya berorientasi pada kepentingan ekonomi saja tanpa memperhatikan kaidah keberlanjutan dari lingkungan dan pelestarian sumber daya alam itu sendiri. Berdasarkan penelusuran diketahui bahwa dalam kurun waktu beberapa tahun terakhir, wilayah pesisir di Teluk Kupang ini telah mengalami perubahan yang cukup signifikan sejak adanya bangunan berupa hotel-hotel, restoran, pertokoan dan industri. Bangunan-bangunan tersebut menyebabkan adanya reklamasi pantai karena dibangun tepat berada di wilayah pesisir Teluk Kupang. Degradasi lingkungan pesisir ini terjadi juga didukung dengan adanya aktivitas oknum masyarakat sekitar dalam melakukan penangkapan ikan dengan tidak bersifat ramah lingkungan.

Oleh karena itu, pengelolaan wilayah pesisir perlu dilakukan dengan baik dan melibatkan seluruh elemen baik pihak pemerintah, swasta, maupun masyarakat setempat yang bersinggungan langsung dengan lingkungan pesisir. Tujuan utama dalam pengelolaan sumberdaya dan lingkungan pesisir yang berkelanjutan di antaranya adalah untuk menjaga kelestraian sumberdaya dan lingkungan serta meningkatkan kesejahteraan seluruh masyarakat yang berada di wilayah pesisir. Dalam hal ini, ada beberapa aspek yang harus diperhatikan yakni aspek ekologi, sosial, dan budaya masyarakat yang dianut oleh masyarakat setempat yang sifatnya berkelanjutan. Aspek ekologi bisa diterapkan dalam fungsi-fungsi ekosistem, sedangkan untuk aspek sosial budaya dapat tercermin dari kearifan lokal yang masih dianut oleh masyarakat setempat (Asagabaldan, 2017). Aspek-aspek tersebut menjadi modal penting dalam upaya melestarikan sumber daya dan lingkungan pesisir. Apalagi saat ini, sejak adanya desentralisasi yang mengubah hukum Indonesia bahwa kewenangan pengelolaan wilayah pesisir dan laut dapat melibatkan masyarakat lokal melalui kemitraan dan mendorong masyarakat untuk berpartisipasi dalam pengelolaan wilayah pesisir dan laut dalam bentuk penerapan kearifan lokal.

Masyarakat di wilayah pesisir Teluk Kupang mempunyai hukum adat yang mampu mendukung keberlangsungan sumber daya alam dan lingkungan pesisir yakni hukum adat lilifuk atau masyarakat setempat juga mengenalnya dengan istilah atolan alat lilifuk. Hukum adat ini berlaku di wilayah pesisir Desa Kuanheun, Kecamatan Kupang Barat, Kabupaten Kupang. Perairan laut Desa Kuanheun merupakan bagian dari Taman Nasional Perairan (TNP) Laut Sawu (Supriatna, 2018). Lilifuk menjadi salah satu kearifan lokal yang telah ada sejak lama dan diterapkan dengan tujuan untuk mendukung pengelolaan atau konservasi pesisir dan laut secara berkesinambungan melalui penangkapan ikan dengan alat dan cara 
ramah lingkungan. Lilifuk telah membentuk suatu hukum adat yang diharuskan untuk dapat dipatuhi dan diikuti oleh seluruh masyarakat pesisir khususnya yang berada di Desa Kuanheun. Meskipun hukum adat lilifuk ini merupakan kearifan lokal namun tetap tidak lepas dari peraturan-peraturan pemerintah khususnya Kementerian Kelautan dan Perikanan (KKP) sehingga lilifuk sejalan dengan harapan yang dicanangkan oleh pemerintah dalam pengelolaan sumber daya pesisir dan keberlangsungannya.

Secara etimologi, lilifuk berasal dari bahasa Dawan (bahasa Suku Timor), yaitu kata 'nifu' yang berarti kolam. Disebut kolam karena lilifuk merupakan sebuah cekungan di permukaan dasar perairan pantai yang digenangi air pada saat surut tertinggi (Supriatna, 2018). Lilifuk adalah suatu kolam besar yang dipenuhi dengan padang lamun yang kaya akan ikan lada (banonang) dan ikan dusung yang berada di tepi laut. Cekungan ini menyerupai kolam yang berukuran besar dengan kedalaman maksimum 5 (lima) meter dan luasnya mencapai $\pm 20.000 \mathrm{~m}^{2}$. Pada saat air laut surut, lilifuk akan dipenuhi dengan berbagai biota laut yang terjebak di dalamnya. Biota tersebut antara lain ikan lada, ikan dusung, dan berbagai jenis rumput laut. Ketetapan mengenai pengelolaan lilifuk dibuat oleh Suku Baineo sebagai tuan tanah (pah tuaf) atau pemilik dari lilifuk. Ketetapan tersebut berisi beberapa hal yakni: (1) panen lilifuk dilakukan setahun sekali pada bulan Desember yang dikenal dengan istilah 'tut nifu', (2) ketika akan melakukan panen, diwajibkan untuk mengundang seluruh masyarakat desa termasuk desa-desa tetangga, (3) setiap orang dilarang untuk memasuki atau mengambil biota laut di wilayah lilifuk di luar dari waktu panen yang ditetapkan, (4) pada saat panen, setiap orang wajib menggunakan alat penangkapan ikan yang tidak merusak lilifuk, (5) setiap orang yang mengikuti panen diwajibkan untuk memberikan upeti kepada Suku Baineo berupa beberapa ekor ikan dari hasil tangkapannya, istilah pemberian upeti ini disebut 'tanaib ika' yang berarti 'memotong hasil ikan atau seikat ikan', dan (5) setiap orang yang melakukan pelanggaran terhadap ketetapan Suku Baineo dikenakan sanksi adat yakni denda (opat) berupa seekor babi (fafi) dan bagi pelaku yang menggunakan alat tangkap pukat garu yang dapat mengakibatkan rusaknya lilifuk akan dikenakan sanksi adat berupa uang Rp. 1.000.000,--

\section{Pembahasan}

Implementasi pengelolaan lilifuk memiliki elemen-elemen masyarakat yang berperan penting yakni tokoh agama, tokoh adat, pemerintah desa, masyarakat, dan orang yang berasal dari luar desa yang masing-masing unsur tersebut memiliki tanggung jawab dan fungsinya sesuai peran yang diberikan (Maharani Yulisti, 2014). Tokoh agama dan pemerintah desa berperan dalam pengambil kebijakan, pertimbangan, dan pemberian dukungan dalam penerapan peraturan yang telah disepakati. Selain itu, pemerintah desa juga bertugas dalam menginformasikan kepada seluruh masyarakat tatkala lilifuk telah dibuka.

Tokoh adat memiliki peran sebagai penjaga sumber daya perikanan seperti karang, lamun, habitat, ekosistem, khususnya ikan-ikan yang ada di dalam lilifuk dan membantu pemerintah desa dalam pengawasan dan menghimpun informasi terhadap pencurian ikan (illegal fishing). Sementara peran masyarakat antara lain dalam perihal menjaga kolam lilifuk dengan mematuhi peraturan yang telah dibuat bersama. Kearifan lokal adalah gagasan lokal yang arif, penuh kearifan, nilai yang baik, yang tertanam dan diikuti oleh anggota masyarakat yang berupa budaya, norma, nilai, etika, kepercayaan, hukum adat, adat istiadat serta aturan khusus (Hartini et al., 2018).

Dalam perannya, lilifuk mampu menjadi jurus jitu dalam pengelolaan sumber daya laut dengan menerapkan beberapa larangan seperti (1) dilarang menggunakan alat tangkap yang merusak lilifuk (kais taleu talas), (2) dilarang melakukan penangkapan ikan di lilifuk jika bukan waktunya (at panen an mui oras), (3) dilarang mengambil penyu (kaisat het hek ke), (4) dilarang mengambil pasir dan batu laut (kais taitis snaen), (5) dilarang mencemari 
laut (kais taleu tasi), dan (6) dilarang merusak tempat pengeringan garam (kais taleu atoni in masi) (Supriatna, 2018). Dalam proses penangkapan ikan dapat dilakukan oleh masyarakat di desa tersebut maupun masyarakat dari luar desa yang biasanya dilakukan dalam waktu dua hari atau tergantung dengan keputusan pemilik lilifuk. Setiap pembukaan lilifuk akan ada seremoni pesta adat dan ritual agama yang perlu dilakukan sebelum melakukan proses panen ikan.

Tercapainya pemanfaatan yang optimal dan berkelanjutan dalam pengelolaan perikanan yang sehat akan mengakibatkan lahirnya beragam kajian potensi, pemanfaatan dan konservasi, penelitian akan pengembangan, serta pengawasan terhadap sumber daya ikan dan lingkungan yang dikelola secara sistematis. Indikator utama yang melandasi hal tersebut adalah dengan beragamnya keanekaragaman hayati yang ada serta perannya yang sangat strategis sebagai penyangga kehidupan dan saling memelihara kehidupan yang disebabkan adanya mata rantai ekologi (Burhanuddin, 2019).

Upaya melegalisasi nilai-nilai tradisional dalam pemanfaatan dan pelestarian sumber daya pesisir telah dilakukan oleh lembaga pemerintahan desa melalui Peraturan Desa Nomor 1 tahun 2012 tentang Perlindungan Sumberdaya Laut di wilayah lilifuk. Peraturan merupakan bentuk antusias dari masyarakat dan beberapa elemen di Desa Keunheun untuk selalu menjaga kearifan dalam pelestarian sumberdaya pesisir dan laut. Dalam Peraturan desa ini, terdapat larangan-larangan yang disertai dengan 12 sanksi bagi setiap pelanggar. Menurut (Fajari et al., 2016) bahwa peran hukum laut merupakan suatu cabang ilmu hukum yang sangat menonjol antar kawasan pesisir untuk segala macam kegiatan yang ada di perairan. Hal tersebut dilandasi dengan luas perairan Indonesia yang dijadikan dasar sehingga perlu adanya pembagian kewenangan di wilayah kelautan serta banyaknya pelanggaran yang dilakukan oleh masyarakat terhadap sumber daya kelautan (Utomo, 2020).

Beberapa sanksi yang telah dibuat oleh Perdes ini, di antaranya setiap orang yang menggunakan pukat garu dalam lilifuk dikenai sanksi adat berupa denda satu juta rupiah dan beras $100 \mathrm{~kg}$, setiap orang yang menggunakan sorok lingkar dikenakan sanksi Rp 500.000. Juga ada sanksi bagi setiap orang yang melakukan penangkapan ikan dengan bubu, menangkap penyu, penggunaan bom dan racun ikan, merusak terumbu, pencemaran perairan dan pengrusakan tempat pengeringan garam. Selain mengatur dalam kegiatan penangkapan, Perdes ini juga mengatur pengelolaan wilayah pesisir dalam bidang lain seperti budidaya, pariwisata, dan pertambangan pasir laut.

Dalam hukum adat lilifuk terdapat setidaknya tujuh nilai-nilai kebaikan yang dapat menumbuhkan pribadi masyarakat yang penuh dengan keteraturan dalam hidup. Nilai-nilai yang terkandung dalam hukum adat lilifuk tersebut yakni:

1) Nilai religius. Masyarakat Kuanheun pada umumnya meyakini bahwa ada kekuatan yang menguasai laut yang disebut dengan Raja Laut (Uis Tasi) sehingga melahirkan kepercayaan bahwa apabila seseorang melakukan pelanggaran hukum adat lilifuk, maka orang tersebut akan memperoleh kesialan. Hal ini juga didukung dengan adanya kepercayaan bahwa lilifuk dijaga oleh kekuatan gaib.

2) Nilai ekologi. Nilai ekologi diperoleh dari aturan lilifuk yang menyatakan bahwa dalam melakukan penangkapan ikan, setiap orang wajib mengggunakan alat tangkap yang ramah lingkungan yang dalam istilah adatnya disebut dengan 'het ika at paek at paek bale le kana teu tasi' yang artinya menangkap ikan menggunakan alat yang tidak merusak laut.

3) Nilai komunal. Sebagai tuan tanah dari lilifuk, tidak membuat Suku Baineo memiliki lilifuk secara mutlak meskipun berkuasa terhadap lilifuk tersebut karena hasil dan manfaat dari lilifuk tersebut tetap akan dapat dirasakan oleh seluruh masyarakat Desa Kuanheun. Selain itu, dalam menyelesaikan setiap pelanggaran lilifuk pun harus dilakukan secara musyawarah dan mufakat dengan melibatkan berbagai pihak dan masyarakat.

4) Nilai relasi sosial. Adanya hukum adat lilifuk memberi pengajaran kepada kita tentang 
bagaimana manusia seharusnya membangun relasi sosial yang baik, harmonis, seimbang, serasi, dan selaras baik antar manusia, maupun manusia dengan lingkungannya. Hal ini tercermin dari proses panen bersama dan musyawarah yang dilakukan dalam menyelesaikan permasalahan. Kesadaran bahwa lingkungan sebagai bagian dari hidup manusia menjadikan hubungan mereka dengan lingkungan juga sangat dijaga.

5) Nilai solidaritas dan tanggungjawab. Nilai solidaritas dan tanggungjawab dapat dilihat dari adanya upaya konservasi yang dilakukan melalui hukum adat lilifuk oleh masyarakat Kuanheun terhadap keberlangsungan biota laut dan lingkungan pesisir. Melalui aturan menagkap ikan dengan alat ramah lingkungan telah memberikan perhatian terhadap kelangsungan kehidupan laut.

6) Nilai kepemimpinan sosial. Nilai ini tergambarkan melalui adanya pengakuan dan penghargaan terhadap keberadaan pemimpin adat yang ada dalam hukum adat lilifuk. Tercermin dari adanya kepatuhan masyarakat terhadap keputusan yang dibuat oleh para pemimpin adat. Peran dan tugas yang dilakukan oleh para pemimpin tersebut telah membangun rasa kepemimpinan di dalam masyarakat. Nilai ini juga dapat terlihat dari sikap masyarakat jika ingin melakukan sesuatu di wilayah tuan tanah, maka akan meminta izin terlebih dahulu kepada tuan tanah yang dikenal dengan ungkapan 'a etun auf tuaf' yang berarti 'kasih tahu tuan tanah'.

7) Nilai pendidikan. Dalam proses hukum adat lilifuk banyak hal yang menjadi sarana pembelajaran seperti perihal ekologi, komunal (kebersamaan), solidaritas dan tanggungjawab, relasi sosial, dan kepemimpinan sosial.

Selain itu, pemahaman tentang pentingnya menjaga lingkungan dan bagaimana seharusnya manusia menjalin hubungan yang baik dan harmonis dengan sesama dan lingkungan juga menjadi sumber pembelajaran bagi siapa pun. Pendekatan tersebut mengakibatkna masyarakat tidak sekedar meniru atau menerima saja informasi yang disampaikan, tetapi sampai menciptakan makna, pemahaman dan arti dari informasi yang diperolehnya (Hasriyanti, 2021).

Terdapat beberapa tahapan penyelesaian yang dilakukan ketika ada yang melanggar aturan-aturan yang telah diterapkan dalam lilifuk, tahapan pertama yaitu melakukan pelaporan ( kepala desa (temukung), lembaga adat (amnais alat), kepala suku Baineo ataupun amnasit. Pihak yang melaporkan dapat dilakukan oleh korban, pelaku (asanat), maupun orang lain. Proses pelaporan ini dikenal dengan istilah 'mu ota lasi' yang berarti 'menceritakan masalah atau pelanggaran'. Ada juga yang menyebut proses pelaporan ini dengan istilah 'tatek oko mama' yang berarti membawa atau mendudukkan tempat sirih' apabila yang melaporkan masalah adalah pelaku itu sendiri. Artinya, pelaku mengakui kesalahannya dan langsung meminta maaf yang dilambangkan dengan membawa tempat sirih (oko mama).

Kedua, tahapan perundingan. Semua pihak yang terkait melakukan perundingan ketika ada laporan yang masuk, istilah perundingan ini dikenal dengan istilah 'tok ta bua' yang berarti 'duduk bersama'. Dalam proses perundingan ini para pihak berwenang akan menentukan sanksi yang diberikan dengan terlebih dahulu mendengarkan saksi yang bisa dipercaya dan mengetahui permasalahan atau pelanggaran yang dilakukan. Ketiga, tahapan putusan yang dikenal dengan istilah 'tafek lasi'. Tahapan ini menyampaikan hasil perundingan terkait sanksi yang diberikan dengan terlebih dahulu memberikan nasehat dan pedoman hidup oleh salah satu pihak yang telah dipercaya. Sanksi yang diberikan biasanya berupa sanksi denda (opat). Keempat, tahapan eksekusi putusan yang disebut juga dengan istilah 'ta naoba fekat'. Pelaksanaan putusan ini didahului dengan melakukan penyembelihan hewan denda yang dibawa oleh pelaku. Hewan tersebut akan dimasak dan dinikmati bersama oleh lembaga adat, kepala desa, amnasit, pelaku, dan juga masyarakat. Kegiatan makan bersama ini melambangkan adanya pengikatan diri terhadap ketetapan hukum adat, terutama 
bagi pelaku untuk kembali mengikatkan dirinya kepada hukum adat yang telah dilanggarnya sehingga di kemudian hari tidak lagi melakukan pelanggaran. Selain itu, tujuan tahapan ini adalah memmbersihkan diri pelaku dari kesalahan yang telah dibuat sekaligus memperbaiki hubungan dengan masyarakat lainnya pasca pelanggaran.

\section{SIMPULAN}

Eksistensi kearifan lokal hukum laut lilifuk di Nusa Tenggara Timur telah memberikan sumbangsih yang cukup besar terhadap kelestarian daerah pesisir khususnya keberlangsungan sumber daya kelautan yang ada di sekitarnya. Kearifan lokal Lilifuk menjadi media yang baik dalam pemanfaatan dan pengelolaan sumber daya yang ada di wilayah pesisir Nusa Tenggara Timur. Melalui nilai-nilai kebaikan yang dimunculkan dari kearifan lokal ini menjadikan lilifuk sangat berperan penting dalam pelestarian sumber daya kelautan yang ada, tidak hanya menghasilkan sebuah mekanisme pengelolaan yang baik namun juga menelurkan nilai-nilai sosial yang diperlukan dalam bermasyarakat. Hal ini mencerminkan adanya keselarasan antara kebutuhan ekonomi, kepentingan masyarakat, dan keperluan dalam pelestarian lingkungan.

Kehadiran hukum adat lilifuk di tengah-tengah masyarakat Nusa Tenggara Timur secara tidak langsung menegaskan betapa pentingnya kearifan lokal dalam mendukung pelestarian lingkungan, baik lingkungan hidup bahkan lingkungan sosial. Artinya, sebuah harapan besar di Indonesia agar berbagai jenis kearifan lokal yang dimiliki dapat tetap dipertahankan sebagai upaya dalam pelestarian lingkungan. Dengan demikian, dapat disimpulkan bahwa hukum adat lilifuk adalah suatu budaya penangkapan ikan dengan alat dan cara yang ramah lingkungan dengan memperhatikan kelestarian ekosistem pesisir dan juga keberlangsungan biota yang ada. Sehubungan adanya aturan dan hukum adat lilifuk, masyarakat khususnya para nelayan tidak dapat menangkap ikan secara bebas di area yang telah disepakati sebelumnya.

\section{SARAN}

Berdasarkan hasil penelitian diatas maka disarankan kepada semua pihak untuk terus melestarikan kearifan lokal yang ada di wilayah Nusa Tenggara Timur, salah satunya yaitu lilifuk. Melestarikan kearifan lokal adalah tugas seluruh elemen masyarakat serta pemerintah terkait sehingga keberlangsungan kearifan lokal lilifuk dapat dirasakan dimasa yang akan datang oleh anak cucu kita.

\section{DAFTAR RUJUKAN}

Asagabaldan, M. A. (2017). HUKUM DAN PERAN LILIFUK DI TENGAH REZIM PEMERINTAHAN: Analisis Hukum dan Keberlanjutan Kearifan Lokal di Desa Kuanheun, Kabupaten Kupang Barat, Nusa Tenggara Timur . Sabda Volume 12 Nomor 2, 2.

Banda, M. M. (2019). UPAYA KEARIFAN LOKAL dalam Menghadapi Tantangan Perubahan Kebudayaan . Jurnal Ilmu-Ilmu Budaya, 1.

Basyari, H. I. (2014). NILAI-NILAI KEARIFAN LOKAL (LOCAL WISDOM) TRADISI MEMITU PADA MASYARAKAT CIREBON (Studi Masyarakat Desa Setupatok Kecamatan Mundu). Edunomic, 48.

Awaliyah, N. R., Hasriyanti, H., \& Maddatuang, M. (2020). Kearifan Lokal Paseng Ri Ade'dan Pemberdayaan Masyarakat Adat Karampuang dalam Upaya Pelestarian Hutan. LaGeografia, $18(3)$.

Burhanuddin, A. I. (2019). Membangun sumber daya kelautan Indonesia: gagasan dan pemikiran guru besar Universitas Hasanuddin. PT Penerbit IPB Press.

Christiawan, P. I., \& Budiarta, I. G. (2017). ENTITAS PERMUKIMAN KUMUH DI WILAYAH PESISIR. Jurnal Ilmu Sosial Dan HumanioraIlmu Sosial Dan Humaniora, 6(2). 
Darmalaksana, W. (2020). Metode Penelitian Kualitatif Studi Pustaka dan Studi Lapangan. Pre-Print Digital Library UIN Sunan Gunung Djati Bandung.

Fajari, Z., Soemarmi, A., \& Hananto, U. D. (2016). Pelaksanaan Peraturan Menteri Kelautan Dan Perikanan Republik Indonesia Nomor 1 Tahun 2015 Tentang Penangkapan Lobster (Panulirus Spp), Kepiting (Scylla Spp), Dan Rajungan (Portunus Pelagicus Spp) Sebagai Upaya Pelestarian Sumber Daya Hayati Laut. Diponegoro Law Journal, 5(2), 1-15.

Fajarini, U. (2014). Peranan kearifan lokal dalam pendidikan karakter. SOSIO-DIDAKTIKA: Social Science Education Journal, 1(2), 123-130.

Hartini, S., Isnanda, M. F., Wati, M., Misbah, M., An'Nur, S., \& Mahtari, S. (2018). Developing a physics module based on the local wisdom of Hulu Sungai Tengah regency to train the murakata character. Journal of Physics: Conference Series, 1088(1), 12045.

Hasriyanti, H. (2021). Pembelajaran Terintegrasi Budaya Lokal Melalui Tradisi Maccera Siwanua. LaGeografia, 19(2), 251-261.

Keraf, A. S. (2010). Etika lingkungan hidup. Penerbit Buku Kompas.

Priyatna, M. (2017). Pendidikan karakter berbasis kearifan lokal. Edukasi Islami: Jurnal Pendidikan Islam, 5(10).

Rahyono, F. X. (2009). . Jakarta: Wedatama Widyasastra. Kearifan Budaya Dalam Kata.

Rinaldi, A., Citra, I. P. A., \& Christiawan, P. I. (2020). Strategi Pengembangan Wilayah Pesisir di Kecamatan Seririt Kabupaten Buleleng. LaGeografia, 19(1), 71-87.

Sugiyono, P. (2019). Metode Penelitian Pendidikan (Kuantitatif, Kualitatif, Kombinasi, R\&D dan Penelitian Pendidikan) (A. Nuryanto (ed.); Ke-3). Alfabeta.

Sulaiman, S. (2010). Model Alternatif Pengelolaan Perikanan Berbasis Hukum Adat Laot di Kabupaten Aceh Jaya Menuju Keberkelanjutan Lingkungan yang Berorientasi Kesejahteraan Masyarakat. Universitas Diponegoro.

Suman, A., \& Satria, F. (2013). Strategi pengelolaan sumber daya udang laut dalam secara berkelanjutan di Indonesia. Jurnal Kebijakan Perikanan Indonesia, 5(1), 47-55.

Surbakti, J. A., \& Leonak, S. P. P. (2020). Kajian Profil Kearifan Lokal Lilifuk: Traditional Ecological Knowledge (Tek) di Desa Kuanheum. JURNAL SUMBERDAYA AKUATIK INDOPASIFIK, 4(2), 183-192.

Syarif, E., Hasriyanti, H., Fatchan, A., Astina, I. K., \& Sumarmi, S. (2016). Conservation Values Of Local Wisdom Traditional Ceremony Rambu Solo Toraja's Tribe South Sulawesi As Efforts The Establishment Of Character Education. EFL JOURNAL, 1(1), 17-23.

Utomo, W. S. (2020). IMPLEMENTASI KEWENANGAN DINAS KELAUTAN DAN PERIKANAN DALAM MELAKUKAN PENGELOLAAN DAN PENGAWASAN TERHADAP SUMBER DAYA KELAUTAN DI TERITORIAL 0 SAMPAI 12 MIL LAUT BERDASARKAN UU NO. 23 TAHUN 2014 TENTANG PEMERINTAHAN DAERAH (Studi di Dinas Kelautan dan Perikanan Provinsi Jawa Timur). Dinamika: Jurnal Ilmiah Ilmu Hukum, 26(1), 12-26.

Yulisti, M., Kurniasari, N., \& Yuliaty, C. (2014). Analisis Keberlanjutan Lilifuk: Tinjauan Persepsi Masyarakat Lokal. Jurnal Sosial Ekonomi Kelautan Dan Perikanan, 9(1), 92-103. 